\title{
Screening for Sarawak Paddy Landraces with Resistance to Yellow Rice Stem Borer, Scirpophaga incertulas (Walker) (Lepidoptera: Crambidae)
}

\author{
Alvin Xian Rong Ling', Freddy Kuok San Yeo ${ }^{1 *}$, Nur Najwa Hamsein ${ }^{2}$, Hieng \\ Ming Ting ${ }^{3}$, Mogeret Sidi ${ }^{1}$, Wan Nurainie Wan Ismail ${ }^{1}$, Annebell Stphanie Taji ${ }^{1}$ \\ and Yin Hui Cheok ${ }^{1}$
}

\author{
${ }^{1}$ Faculty of Resource Science and Technology, Universiti Malaysia Sarawak, 94300 Kota Samarahan, \\ Sarawak, Malaysia \\ ${ }^{2}$ Agriculture Research Centre, Semongok, P.O.Box 977, 93720 Kuching, Sarawak \\ ${ }^{3}$ Institute of Plant Biology, National Taiwan University, Taipei 10617, Taiwan
}

\begin{abstract}
The yellow rice stem borer, Scirpophaga incertulas (Walker) is a prevalent pest in paddy fields worldwide. In Sarawak, a survey on pest of paddy carried out from 2009 to 2011 covering 166 paddy fields revealed that rice stem borers caused $11.4 \%$ of total paddy damage. In order to reduce the damage, identifying resistance paddy variety is crucial. The objective of this study was to screen Sarawak paddy landraces with resistance to S. incertulas. Twelve Sarawak paddy landraces were selected randomly for this

ARTICLE INFO

\section{Article history:}

Received: 29 May 2020

Accepted: 17 August 2020

Published: 27 November 2020

DOI: https://doi.org/10.47836/pjtas.43.4.06

E-mail addresses:

alvinlingxr@gmail.com (Alvin Xian Rong Ling)

yksfreddy@unimas.my (Freddy Kuok San Yeo)

nurnh@sarawak.gov.my (Nur Najwa Hamsein)

jimmytinghm@ntu.edu.tw (Hieng Ming Ting)

smogeret@unimas.my (Mogeret Sidi)

wiwnurainie@unimas.my (Wan Nurainie Wan Ismail)

annebellannebel1221@gmail.com (Annebell Stphanie Taji)

yinhuic56@gmail.com (Yin Hui Cheok)

*Corresponding author

study. Antixenosis resistance screening was performed in aquariums $(60 \times 28 \times$ $33 \mathrm{~cm}$ ). Three replications of one-monthold seedlings were randomly arranged in aquarium and exposed to adult $S$. incertulas. The number and position of egg mass on each plant were recorded. Egg mass abnormalities were also observed. For antibiosis, rice culms of two-month old seedlings from each landrace were infested with larvae. The length of surviving larvae from five rice culms was measured. The experiment revealed variations in landrace
\end{abstract}


of preference for ovipositing. Among the twelve Sarawak paddy landraces, Kanowit was more preferred by $S$. incertulas for ovipositing in comparison to other paddy landraces suggesting susceptibility towards the pest. Abaxial leaf surface was the preferred oviposition site. There was no clear antibiosis response of the paddy landraces towards $S$. incertulas larvae in this study.

Keywords: Antibiosis, antixenosis, rice insect pest

\section{INTRODUCTION}

Cultivated rice, Oryza sativa is one of the dominant staple foods in many countries, especially in the Asian region. However, insect pests remain to be one of the major threats to the quantity and quality of rice production (Bhadauria \& Singh, 2009). Generally, among many insect rice pests, the stem borer stands out as one of the most serious pests due to the wide-scale damage on crop yield (Khan et al., 2003). A statewide rice pest survey in 166 rice fields in Sarawak, rice stem borer infestation has been found responsible for $11.4 \%$ of rice damage in the fields of Sarawak (Gumbek \& Hamsein, 2011). Yellow rice stem borer, Scirpophaga incertulas (Walker) is one of the stem borer species found commonly throughout the fields of South East Asia and accounts to the highest overall damage (Chakraborty \& Deb, 2008; Hugar et al., 2010). S. incertulas is also found throughout the rice fields in Sarawak.

Adults of $S$. incertulas are harmless to rice plants. The larvae, however, can cause significant damage via burrowing and feeding on the rice stem (Satpathi et al., 2012). Damages by yellow rice stem borer has been detected in different growth stages ranging from seedlings to adult plants (Dale, 1994; Hamsein et al., 2020). Symptoms of infestation in the early stages are concealed and will only become apparent in later stages. A common symptom of infestation during the vegetative phase of rice is known as dead heart, a condition where the leaf base is destroyed, causing the leaves to dry out. Another symptom during the generative phase, white head, occurs when the stem is attacked, causing the panicles to be cut off from water and nutrient, leading to desiccation (Bashir et al., 2004).

Usage of insecticide has been found to aggravate damage done by rice stem borer due to the elimination of the predators and parasites of rice stem borer. Rice stem borer infestation has been found to be significantly higher in areas practicing chemical control, compared to areas in Sarawak where insecticide is seldom used (Rothschild, 1970). As a result, a more effective and sustainable control method has to be introduced. One of the alternatives to control insect pest is by planting resistant variety. Resistance is determined by the presence of antibiosis and antixenosis properties in plant. These mechanisms allow a plant to appear unfavourable as a target of infestation by insect pest. Resistance towards insect pest is an efficient and durable built-in control measure, convenient and does not cause harm to human health or the environment (Chaudhary et al., 1984). 
Different paddy variety/landraces may have different resistance level (Devasena et al., 2018). Varieties/landraces known to have resistance are valuable candidates for resistance breeding. The objective of this study was to screen Sarawak paddy landraces with resistance to $S$. incertulas.

\section{METHODS}

\section{Seedlings Preparation}

A total of twelve locally collected wetland paddy landraces were used in this experiment (Table 1). The seeds were germinated by soaking in distilled water and sowed in planting trays. For antixenosis experiment, healthy seedlings were selected and transplanted randomly (three seedlings per landrace) into an enclosed aquarium (60 x 28 x $33 \mathrm{~cm}$ ) filled with planting media consisting of topsoil and sand (2:1). There were six landraces per aquarium. Onemonth-old rice plants were used.

For antibiosis experiment, healthy seedlings were transplanted into pots $(\varnothing=$ $30 \mathrm{~cm}$; 16L) filled with planting media as mentioned earlier (five seedlings per pot). Culms of $20 \mathrm{~cm}$ were harvested from twomonth-old rice plants for experimental usage. Compound fertilizer $12 \mathrm{~N}: 12 \mathrm{P}_{2} \mathrm{O}_{5}$ : $17 \mathrm{~K}_{2} \mathrm{O}: 2 \mathrm{MgO}+\mathrm{TE}$ was applied at the rate of $\approx 9.7 \mathrm{~g}$ per aquarium and $\approx 2.4 \mathrm{~g}$ per pot biweekly until the plants were ready for use.

\section{Antixenosis Experiment - Choice Experiment}

One-month-old plants (in aquarium) were subjected to $S$. incertulas infestation.

Table 1

Twelve wetland paddy landraces subjected to Scirpophaga incertulas infestation

\begin{tabular}{lll}
\hline Landrace & Code & Seed Source \\
\hline Padi Pulut & UNISRA-11 & Kg. Paun Gahat \\
Padi Hitam & UNISMT-21 & Kg. Pueh \\
Padi Segangging & UNISRA-25 & Melugu Skim \\
Padi Kanowit & UNISRA-26 & Melugu Skim \\
Padi Merawi & UNIPDW-51 & Padawan \\
Padi Adan & UNIBKN-61 & Long Semadoh, Ba'kelalan \\
Padi Rutan & UNISRA-33 & Sg. Tenggang \\
Padi Upah & UNISRA-35 & Sg. Tenggang \\
Padi Merah & UNIPDW-18 & Kg. Pesak \\
Padi Selasih & UNISRA-40 & Melugu Skim \\
Padi Labat & UNISMT-23 & Kg. Pueh \\
Padi Pulut Hitam & UNISMT-22 & Kg. Pueh \\
\hline
\end{tabular}


Female $S$. incertulas were collected from the paddy field of Kampung Skuduk-Chupak $\left(1^{\circ} 15^{\prime} 7.12^{\prime} \mathrm{N}, 110^{\circ} 25^{\prime} 59.83^{\prime} \mathrm{E}\right)$ using white screen light trap. A total of 50 adult females were released directly into each aquarium after captured in the field. Three days after infestation, the number and position of egg masses found on the leaves were recorded. Egg mass abnormalities as described by Hilker and Meiners (2006) were recorded. Three repetition were carried out for this experiment. Relative value for number of egg masses (Equation 1) was used for analysis:

Total egg masses on leaf of a plant Total egg masses found on leaf of all plants

\section{[Equation 1]}

Oviposition site of preference, adaxial $v s$. abaxial, was analysed using two-sample $t$-test $(\alpha=0.05)$. Landrace of preference for oviposition was analysed using one-way analysis of variance (ANOVA) $(\alpha=0.05$; using IBM SPSS software version 24).

\section{Antibiosis Experiment - Non-choice Experiment}

The culm $(20 \mathrm{~cm})$ of the paddy landraces were harvested and placed in separate transparent containers (10 culms per container). A moist cotton piece was used to cover the lower end of the culms. One newly hatched $S$. incertulas larva was placed at the top end of each culm. The containers holding the culms were left on lab bench at room temperature $\left(25-27^{\circ} \mathrm{C}\right)$. Seven days after the infestation, the length of surviving larvae from five rice culm was measured using a ruler. Two repetitions were carried out for this experiment and the data was analysed using one-way ANOVA $(\alpha=0.05$; using IBM SPSS software version 24).

\section{RESULTS}

On each plant, 0 to 16 egg masses were found. Size of egg masses ranged from 2 $\mathrm{mm}^{2}$ to $32 \mathrm{~mm}^{2}$. Egg masses were found mostly on the surface of leaf blades, while only 1 - 4 egg masses were found on the stems of plants from each aquarium (Table 2).

Table 2

Egg masses recorded across six aquariums on different surfaces

\begin{tabular}{lllll}
\hline \multirow{2}{*}{ Aquarium } & \multicolumn{2}{c}{ Egg mass on plant } & $\begin{array}{l}\text { Egg mass on non- } \\
\text { plant surface }\end{array}$ & Total egg mass \\
\cline { 2 - 5 } & Leaf & Stem & 14 & 59 \\
\hline 1 & 42 & 3 & 21 & 116 \\
2 & 92 & 3 & 9 & 64 \\
3 & 54 & 1 & 11 & 58 \\
4 & 46 & 1 & 9 & 82 \\
5 & 71 & 2 & 3 & 82 \\
6 & 75 & 4 & & \\
\hline
\end{tabular}




\section{Leaf Surface of Preference by Scirpophaga incertulas for Oviposition}

Between abaxial and adaxial leaf surface, there was a significant different in the number of egg masses found on the abaxial and adaxial surfaces $(p$-value $=0.0001)$. The mean relative numbers of egg masses laid on the abaxial and adaxial surface of paddy landraces were $0.04 \pm 0.003$ and $0.02 \pm$ 0.002 , respectively, where more egg masses were found on abaxial surface.

\section{Antixenosis Resistance of Sarawak Paddy Landraces against Scirpophaga incertulas}

Among the twelve paddy landraces, there was a significant difference in the relative number of egg masses found on the leaf of seedlings ( $p$-value $=0.001)$. In general, the twelve paddy landraces can be grouped into landraces with low (7 landraces), intermediate (4 landraces), and high (1 landrace) number of egg masses (Table 3). The classification is based on the homogenous subsets created by Tukey HSD. The one landrace in the high egg mass number category, Kanowit, was more preferred by the female $S$. incertulas for oviposition (mean relative number of egg masses, $0.12 \pm 0.018$ ) when compared to the landraces in the low egg mass number category. Egg mass abnormalities described by Hilker and Meiners (2006) were not observed (Figure 1). All egg masses were intact, and no drop-off egg masses were seen. There were also no signs of neoplasm formation or necrosis under or around egg masses attached to the plant surface.

\section{Egg mass position}

Figure 1. Egg mass of Scirpophaga incertulas artificially removed from its deposited position on paddy leaf blade. Neoplasm formation or necrosis under or around egg masses was absent 
Antibiosis Resistance of Sarawak Paddy Landraces against Scirpophaga incertulas

All twelve landraces from both repetitions had at least five culms with surviving larvae. The length of larvae removed from the culms measured between $1.5 \mathrm{~mm}$ to $5.2 \mathrm{~mm}$. The average larvae length was measured at $2.9 \mathrm{~mm}$. There was no significant difference in the length of survived larvae ( $p$-value $=$ 0.333) (Table 3).

Table 3

Mean relative number of egg masses oviposited and the larvae length of Scirpophaga incertulas on each paddy landrace

\begin{tabular}{|c|c|c|c|}
\hline Landraces & $\begin{array}{l}\text { Mean relative } \\
\text { number of egg mass } \\
\pm \mathrm{SE}^{*}\end{array}$ & $\begin{array}{l}\text { Grouping based } \\
\text { on mean relative } \\
\text { number of egg mass! }\end{array}$ & $\begin{array}{l}\text { Mean larvae } \\
\text { length }(\mathrm{mm}) \pm \mathrm{SE}^{*}\end{array}$ \\
\hline Padi Merawi & $0.03 \pm 0.009^{\mathrm{a}}$ & Low number & $2.82 \pm 0.312^{\mathrm{a}}$ \\
\hline Padi Pulut & $0.03 \pm 0.009^{a}$ & Low number & $2.97 \pm 0.208^{a}$ \\
\hline Padi Upah & $0.04 \pm 0.012^{\mathrm{a}}$ & Low number & $3.25 \pm 0.214^{\mathrm{a}}$ \\
\hline Padi Hitam & $0.05 \pm 0.011^{\mathrm{a}}$ & Low number & $2.51 \pm 0.137^{\mathrm{a}}$ \\
\hline Padi Adan & $0.05 \pm 0.011^{\mathrm{a}}$ & Low number & $3.07 \pm 0.246^{\mathrm{a}}$ \\
\hline Padi Pulut Hitam & $0.05 \pm 0.013^{\mathrm{a}}$ & Low number & $2.66 \pm 0.273^{\mathrm{a}}$ \\
\hline Padi Merah & $0.05 \pm 0.009^{\mathrm{a}}$ & Low number & $2.74 \pm 0.240^{\mathrm{a}}$ \\
\hline Padi Selasih & $0.06 \pm 0.013^{\mathrm{ab}}$ & Intermediate & $2.73 \pm 0.169^{\mathrm{a}}$ \\
\hline Padi Segangging & $0.06 \pm 0.014^{\mathrm{ab}}$ & Intermediate & $2.99 \pm 0.158^{a}$ \\
\hline Padi Labat & $0.07 \pm 0.014^{\mathrm{ab}}$ & Intermediate & $2.66 \pm 0.193^{a}$ \\
\hline Padi Rutan & $0.07 \pm 0.018^{\mathrm{ab}}$ & Intermediate & $3.14 \pm 0.163^{\mathrm{a}}$ \\
\hline Padi Kanowit & $0.12 \pm 0.018^{\mathrm{b}}$ & High number & $2.73 \pm 0.116^{\mathrm{a}}$ \\
\hline
\end{tabular}

Note. * Means within the same column followed by the same letter are non-significantly different $(p<0.05)$ based on Tukey HSD; ' Grouping is based on homogeneous subsets generated by Tukey HSD

\section{DISCUSSIONS}

Decision of female insects in choosing oviposition site (leaf surface) is crucial for the survival of their larvae. A recent study by Hamsein et al. (2020) had screened six Sarawak paddy landraces for resistance towards $S$. incertulas in a net house environment. The free choice experiment showed that $S$. incertulas preferred to oviposit on the abaxial of leaf surface, and on the leaf of older and taller plants. Adult females of $S$. incertulas showed no specific preference between the six Sarawak paddy landraces for ovipositing. In a nonchoice experiment by Cheok et al. (2019), under uniform age, $S$. incertulas showed no specific preference for ovipositing on adaxial and abaxial leaf surface, as well as 
on the Sarawak paddy landraces tested. In this study, $S$. incertulas showed a preference to oviposit on the abaxial leaf surface in agreement to Shahjahan (2002) and Hamsein et al. (2020). A possible reason for the oviposition choice could be that abaxial side decreases the chance of the egg masses to be exposed to predation and parasitism (Renwick \& Chew, 1994).

It was also observed in this study, under uniform age and plant height, $S$. incertulas showed variations in landrace of preference for ovipositing. The Kanowit paddy landrace seemed to be more preferred for ovipositing by $S$. incertulas as compared to certain landraces. A variation in preference for oviposition by $S$. incertulas was also observed by Rustamani et al. (2002) in a field experiment in Pakistan. The variations of preference may have occurred due to the presence and absence of oviposition deterrent chemicals (antixenosis) between the 12 Sarawak paddy landraces. Evidence of oviposition deterrent chemicals forming after egg mass deposition on plants had been reported for cabbage against Pieris brassicae, the cabbage butterfly (Blaakmeer et al., 1994). According to Bertea et al. (2019), insects produce substances during ovipositing which act as elicitors that triggers plant defence response. The elicitors were able to trigger electrical signals and change $\mathrm{Ca}^{2+}$ homeostasis resulting in defensive responses from the plant through hormone signalling pathways (salicylic acid pathway) (Bertea et al., 2019). The condition may be similar for rice in response to ovipositing of $S$. incertulas. Landrace which is more preferred for ovipositing may not have or have a low level of oviposition deterrent chemicals. However, there is no study yet on such rice response.

To date, 18 Sarawak paddy landraces were used to study the landrace of preference for ovipositing by $S$. incertulas collected from Kampung Skuduk-Chupak $\left(1^{\circ} 15^{\prime} 7.12^{\prime \prime} \mathrm{N}, 110^{\circ} 25^{\prime} 59.83^{\prime} \mathrm{E}\right)$. Only the Kanowit landrace was more preferred by $\mathrm{S}$. incertulas (Table 4). Additional screening and combination of different landraces will allow the identification of susceptible and resistance landrace.

Egg deposition is the precursor to future insect (larvae) infestation (Lortzing et al., 2019). To counteract, hypersensitive response in the form of necrosis and neoplasm formation (antibiosis resistance) has been observed in plants as a lethal direct defence against insect eggs (Petzold-Maxwell et al., 2011). Formation of neoplasm and necrotic tissue may cause attached egg masses to drop off, therefore removing the possibility of larvae hatching and infesting the plant. The egg masses observed in this study were healthy and were attached firmly to the plant surface. Thus, it could be assumed that the 12 paddy landraces lacked antibiosis resistance. Signs of neoplasm and necrotic tissue formation were not observed in areas of egg mass deposition otherwise (Hilker \& Meiners, 2006).

An alternative method of observing antibiosis resistance is by studying larvae growth. Visible effects of antibiosis can be observed on the larvae in the form of high mortality, longer development period 
Alvin Xian Rong Ling, Freddy Kuok San Yeo, Nur Najwa Hamsein, Hieng Ming Ting, Mogeret Sidi, Wan Nurainie Wan Ismail, Annebell Stphanie Taji and Yin Hui Cheok

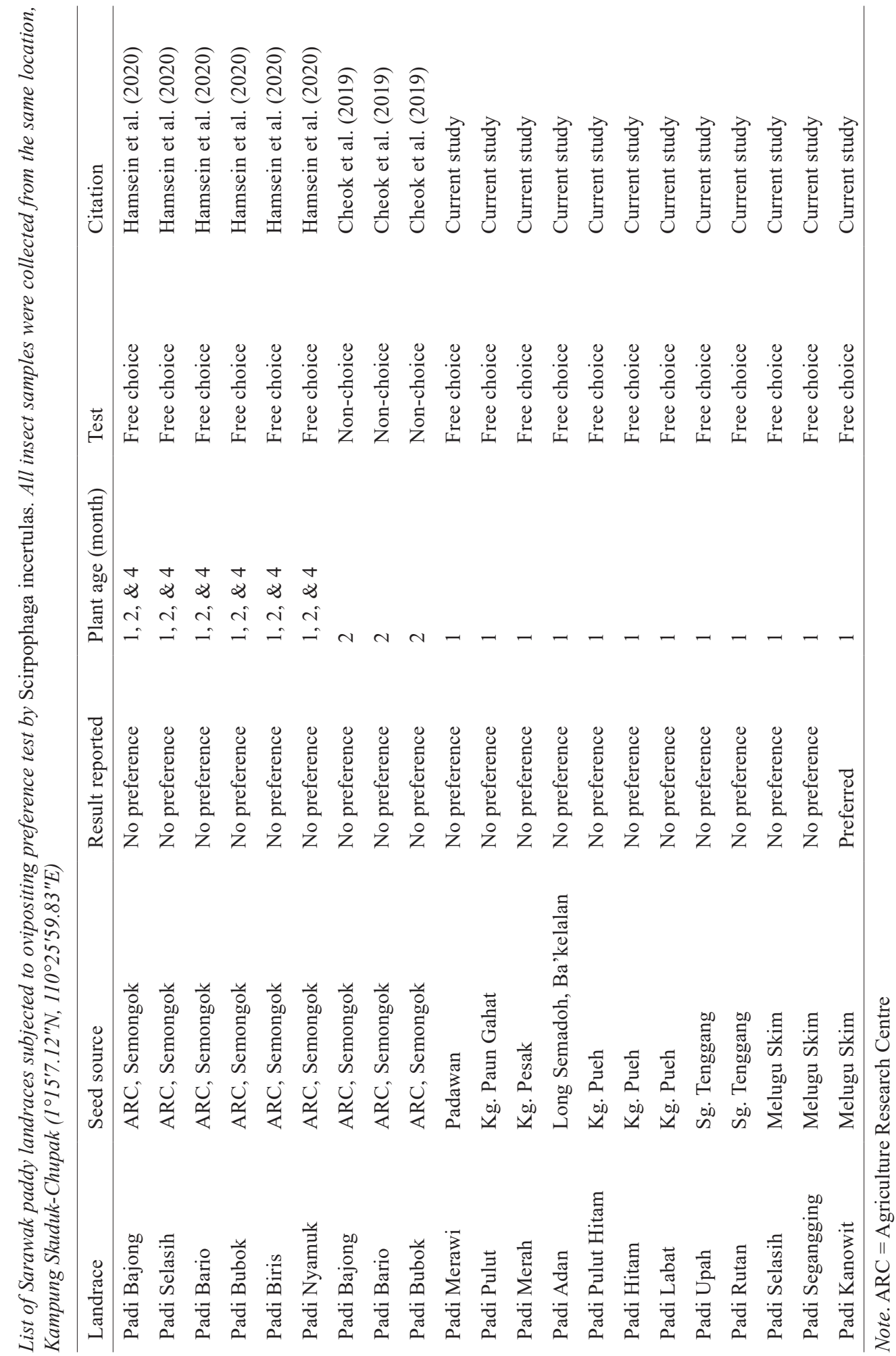


or decreased size (Padmaja, 2016). In the current study, there was no difference in the length of $S$. incertulas larvae infested in culm cuttings of different landraces. This may suggest that the 12 paddy landraces have no antibiosis resistance towards the larvae or among the paddy landraces, there are landraces having weak level of antibiosis resistance which result in insignificant different between them. Presence of antibiosis resistance in rice plants has been proven to exist in rice against Chilo suppressalis (Hosseini et al., 2011; Tabari et al., 2017). According to Hosseini et al. (2011), smaller stem diameter may be one form of resistance associated morphological characteristics that disrupt the $S$. incertulas larvae infestation. A smaller stem diameter provides less feeding space as well as limited food sources for the development of larvae (Hosseini et al., 2010, 2011; Sarwar, 2013).

\section{CONCLUSION}

In conclusion, Scirpophaga incertulas prefers to deposit their egg masses on the abaxial leaf surface of rice plant. The 12 Sarawak paddy landraces vary in the level of antixenosis resistance against $S$. incertulas. Among the landraces, Kanowit is more preferred by $S$. incertulas for ovipositing in comparison to seven other landraces. Antibiosis resistance against the eggs and larvae of $S$. incertulas seems absent.

\section{ACKNOWLEDGEMENT}

This study was funded by Universiti Malaysia Sarawak Small Grant Scheme [F07/(S171)/1273/2015(08)] and the Malaysia Ministry of Education under Fundamental Research Grant Scheme (F07/ FRGS/1608/2017). The authors would like to extend our gratitude to Mr. Chin from Kampung Skuduk-Chupak for his permission to visit and collect sample from his rice field. The authors would also like to thank Ms. Chua Sing Ying and Mr. Ling Xian Lin for their assistance in sample collection.

\section{REFERENCES}

Bashir, K., Husnain, T., Fatima, T., Latif, Z., Mehdi, S. A., \& Riazuddin, S. (2004). Field evaluation and risk assessment of transgenic indica basmati rice. Molecular Breeding, 13(4), 301-312. doi: 10.1023/B:MOLB.0000034078.54872.25

Bertea, C. M., Casacci, L. P., Bonelli, S., Zampollo, A., \& Barbero, F. (2019). Chemical, physiological and molecular responses of host plants to lepidopteran egg-laying. Frontiers in Plant Science, 10, 1768. doi: 10.3389/fpls.2019.01768

Bhadauria, N. S., \& Singh, P. (2009). Assessment of losses in paddy caused by Leptocorisa varicornis. Annals of Plant Protection Sciences, 17(1), 231.

Blaakmeer, A., Hagenbeek, D., Van Beek, T. A., De Groot, A. E., Schoonhoven, L. M., \& Van Loon, J. J. A. (1994). Plant response to eggs vs. host marking pheromone as factors inhibiting oviposition by Pieris brassicae. Journal of Chemical Ecology, 20(7), 1657-1665. doi: 10.1007/BF02059887

Chakraborty, K., \& Deb, D. C. (2008). Incidence and abundance of Scirpophaga incertulas in 
Alvin Xian Rong Ling, Freddy Kuok San Yeo, Nur Najwa Hamsein, Hieng Ming Ting, Mogeret Sidi, Wan Nurainie Wan Ismail, Annebell Stphanie Taji and Yin Hui Cheok

relation to the agro-climatic factors of Raiganj, West Bengal, India and adoption of befitted cultural practices for the pest suppression. North Bengal University Journal of Animal Science, 2(1), 79-89.

Chaudhary, R. C., Khush, G. S., \& Heinrichs, E. A. (1984). Varietal resistance to rice stem-borers in Asia. International Journal of Tropical Insect Science, 5(6), 447-463. doi: 10.1017/ S1742758400004872

Cheok, Y. H., Yeo, F. K. S., \& Chong, Y. L. (2019). Oviposition behaviour of Scirpophaga incertulas, the yellow stemborer (Lepidoptera: Crambidae) in a non-choice study. Pertanika Journal of Tropical Agricultural Science, 42(3), 1167-1172.

Dale, D. (1994). Insect pests of the rice planttheir biology and ecology. In E. A. Heinrichs (Ed.), Biology and management of rice insects (pp. 363-485). New Delhi, India: International Rice Research Institution.

Devasena, N., Soundararajan, R. P., Reuolin, S. J., Jeyaprakash, P., \& Robin, S. (2018). Evaluation of rice genotypes for resistance to yellow stem borer, Scirpophaga incertulas (Walker) through artificial screening methods. Journal of Entomology and Zoology Studies, 6(1), 874-878.

Gumbek, M., \& Hamsein, N. N. (2011). Status of paddy pests in Sarawak. In Proceeding Research Officers Progress Meeting, 4-6 October (p. 13). Kuching, Malaysia: Department of Agriculture Sarawak.

Hamsein, N. N., Yeo, F. K. S., Sallehuddin, R., Mohamad, N. K., Kueh-Tai, F. F., Hussin, N. A., \& Ismail, W. N. W. (2020). Oviposition behaviour of Scirpophaga incertulas (Walker) (Lepidoptera: Pyralidae) on Sarawak rice landraces. Taiwania, 65(1), 95-99. doi: 10.6165/ tai.2020.65.95

Hilker, M., \& Meiners, T. (2006). Early herbivore alert: Insect eggs induce plant defense. Journal of Chemical Ecology, 32(7), 1379-1397. doi: 10.1007/s10886-006-9057-4

Hosseini, S. Z., Babaeian-Jelodar, N., \& Bagher, N. (2010). Evaluation of resistance to striped stem borer in rice. Biharean Biologist, 4(1), 67-71.

Hosseini, S. Z., Jelodar, N. B., Bagheri, N., Alinia, F., \& Osku, T. (2011). Traits affecting the resistance of rice genotypes to rice stem borer. International Journal of Biology, 3(1), 130. doi: 10.5539/ijb. v3n1p130

Hugar, S. V., Venkatesh, H., Hanumanthaswamy, B. C., \& Pradeep, S. (2010). Comparative biology of yellow stem borer, Scirpopahaga incertulas Walker, (Lepidoptera: Pyraustidae) in aerobic and transplanted rice. International Journal of Agricultural Science, 6(1), 160-163.

Khan, M., Saljoqi, A. R., Latif, A., \& Abdullah, K. (2003). Evaluation of some rice varieties against rice stem borer (Tryporyza incertulas). Asian Journal of Plant Science, 2(6), 498-500. doi: 10.3923/ajps.2003.498.500

Lortzing, V., Oberlander, J., Lortzing, T., Tohge, T., Steppuhn, A., Kunze, R., \& Hilker, M. (2019). Insect egg deposition renders plant defence against hatching larvae more effective in a salicylic acid-dependent manner. Plant, Cell and Environment, 42(3), 1019-1032. doi: 10.1111/ pce. 13447

Padmaja, P. G. (2016). Insect pest resistance in sorghum. In Biotic stress resistance in millets (pp. 105-145). Cambridge, USA: Academic Press.

Petzold-Maxwell, J., Wong, S., Arellano, C., \& Gould, F. (2011). Host plant direct defence against eggs of its specialist herbivore, Heliothis subflexa. Ecological Entomology, 36(6), 700-708. doi: 10.1111/j.1365-2311.2011.01315.x

Renwick, J. A. A., \& Chew, F. S. (1994). Oviposition behaviour in Lepidoptera. Annual Review of 
Entomology, 39(1), 377-400. doi: 10.1146/ annurev.en.39.010194.002113

Rothschild, G. H. L. (1970). Parasites of rice stemborers in Sarawak (Malaysian Borneo). Entomophaga, 15(1), 21-51. doi: 10.1007/ BF02371624

Rustamani, M. A., Talpur, M. A., Khuhro, R. D., \& Baloch, H. B. (2002). Oviposition preference and infestation of yellow stem borer in rice varieties. Pakistan Journal of Applied Sciences, 2(8), 831834. doi: 10.3923/jas.2002.831.834

Sarwar, M. (2013). Valuation of some aromatic rice (Oryza sativa L.) genetic materials to achieve tolerant resources for rice stem borers (Lepidoptera: Pyralidae). International Journal of Scientific Research in Environmental Sciences, 1(10), 285-290. doi: 10.12983/ijsres2013-p285-290
Satpathi, C. R., Chakraborty, K., Shikari, D., \& Acharjee, P. (2012). Consequences of feeding by yellow stem borer (Scirpophaga incertulas Walk.) on rice cultivar Swarna mashuri (MTU 7029). World Applied Sciences Journal, 17(4), 532-539.

Shahjahan, M. D. (2002). Oviposition preference of Scirpophaga incertulas (Walker) on different varieties of rice under caged condition. Pakistan Journal of Scientific and Industrial Research, 45(4), 267-272.

Tabari, M. A., Fathi, S. A. A., Nouri-Ganbalani, G., Moumeni, A., \& Razmjou, J. (2017). Antixenosis and antibiosis resistance in rice cultivars against Chilo suppressalis (Walker) (Lepidoptera: Crambidae). Neotropical Entomology, 46(4), 452-460. doi: 10.1007/s13744-016-0479-6 
